\title{
Factors associated with frailty syndrome in the rural elderly
}

\author{
Fatores associados à síndrome da fragilidade em idosos rurais \\ Factores asociados al síndrome de fragilidad en ancianos rurales
}

\section{Patrícia Mirapalheta Pereira de Llano' \\ ORCID: 0000-0002-2746-1398 \\ Celmira Lange \\ ORCID: 0000-0003-4410-2124}

\section{Carlos Alberto da Cruz Sequeira"} ORCID: 0000-0002-5620-3478

Vanda Maria da Rosa Jardim' ORCID: 0000-0001-8320-4321

Denise Somavila Przylynski Castro' ORCID: 0000-0003-2817-2747

Fernanda Santos ORCID: 0000-0001-9153-665X

'Universidade Federal de Pelotas. Pelotas, Rio Grande do Sul, Brazil. "Escola Superior de Enfermagem. Porto, Portugal.

How to cite this article: Llano PMP, Lange C, Sequeira CAC, Jardim VMR, Castro DSP Santos F. Factors associated with frailty syndrome in the rural elderly. Rev Bras Enferm. 2019;72(Suppl 2):14-21. doi: http://dx.doi.org/10.1590/0034-7167-2017-0079

\section{Corresponding Author:} Patrícia Mirapalheta Pereira de Llano E-mail:pati_llano@yahoo.com.br

Submission: 02-07-2017 Approval: 07-19-2018

\section{ABSTRACT}

Objective: determine the prevalence and factors associated with frailty syndrome (FS) in the elderly in the rural population of Pelotas. Method: Quantitative, analytical, transversal study conducted with 820 elderly subjects registered in the Family Health Strategy (FHS) in the rural area in the municipality of Pelotas, from July to October 2014. Results: among those evaluated, $43.41 \%$ showed FS. These factors were consolidated as associated with the condition: low income (PR: 1.54, $p \leq 0.001)$, low educ. level (PR: 1.45, $p \leq 0.001$ ), nutritional status (obesity) (PR:1.89, $p \leq 0.001$ ), physical inactivity (PR:1.93, $p=0.003$ ), cognitive deficit (PR:2.07, $p=0.005)$, and poor self-perceived health (PR: 8.21, $p \leq 0.001)$. Conclusion: the findings may contribute effectively to the establishment of prevention and screening measures for frailty among the elderly by health professionals, especially nurses, aiming to prevent the occurrence of the syndrome and adverse and undesirable outcomes.

Descriptors: The Elderly; Health of the Elderly; The Frail Elderly; Rural Population; Nursing.

\section{RESUMO}

Objetivo: determinar a prevalência e os fatores associados à síndrome da fragilidade em idosos (SFI) da população rural de Pelotas. Método: estudo quantitativo, analítico e transversal realizado com 820 idosos cadastrados na Estratégia Saúde da Família (ESF) na zona rural do município de Pelotas, no período de julho a outubro de 2014. Resultados: entre os avaliados, $43,41 \%$ apresentaram SFI. Consolidaram-se como fatores associados à condição a baixa renda (RP: 1,54, $\mathrm{p} \leq 0.001)$, a baixa escolaridade (RP: 1,45, $\mathrm{p} \leq 0.001$ ), o estado nutricional (obesidade) (RP: $1,89, \mathrm{p} \leq 0,001$ ), a inatividade física (RP: 1,93, $\mathrm{p}=0.003$ ), a apresentação de déficit cognitivo (RP: $2,07, \mathrm{p}=0.005$ ) e a autopercepção de saúde baixa (RP: $8,21, p \leq 0,001)$. Conclusão: os achados podem contribuir efetivamente para o estabelecimento de medidas de prevenção e rastreamento da fragilidade entre as pessoas idosas por parte dos profissionais de saúde, principalmente dos enfermeiros, visando evitar a ocorrência da síndrome e dos desfechos adversos e indesejáveis. Descritores: Idoso; Saúde do Idoso; Idoso Fragilizado; População Rural; Enfermagem.

\section{RESUMEN}

Objetivo: determinar el predominio y los factores asociados al síndrome de fragilidad en ancianos (SFI) de la población rural de Pelotas. Método: estudio cuantitativo, analítico y transversal realizado con 820 ancianos registrados en la Estrategia Salud de la Familia (ESF) en la zona rural del municipio de Pelotas, entre julio y octubre de 2014. Resultados: entre los evaluados, el $43,41 \%$ presentó SFI. Se han consolidado como factores asociados a la condición: la baja renta (RP: $1,54, p \leq 0.001$ ), la baja escolaridad (RP: $1,45, p \leq 0.001$ ), el estado nutricional (obesidad) (RP: 1,89, $p \leq 0,001$ ), la inactividad física (RP: $1,93, p=$ 0.003 ), la presencia de déficit cognitivo (RP: $2,07, p=0.005$ ) y la autopercepción de salud baja (RP: 8,21, p $\leq 0,001$ ). Conclusión: los hallazgos pueden contribuir efectivamente al establecimiento de medidas de prevención y rastreo de la fragilidad entre las personas mayores por parte de los profesionales de salud, principalmente de los enfermeros, con el fin de evitar la ocurrencia del síndrome y de los resultados adversos e indeseables.

Descriptores: Anciano; Salud del Anciano; Anciano Frágil; Población Rural; Enfermería. 


\section{INTRODUCTION}

The change in the demographic and epidemiological profile in Brazil leads to an increase in comorbidities and syndromes in the elderly, due to the process of populational aging and the longevity of people. The frailty syndrome (FS) in the elderly, especially in the rural population, has generated important repercussions for the construction of preventive strategies that prioritize an aging process with greater autonomy and quality of life of older people.

The set of physiological and pathological alterations experienced by the elderly results in their increased dependence, making them frail. Frailty syndrome in the elderly is characterized as reduced physiological reserves and increased vulnerability of individuals, reducing their capacity for homeostatic adaptation, as a result of an internal and progressive process, externalized by a phenotype consisting of five measurable components: unintentional weight loss, fatigue, reduced strength and walking speed, and low physical activity ${ }^{(1)}$.

It is worth noting that the state of Rio Grande do Sul has $13.65 \%$ of the population aged above 60 years, being the fourth in absolute number of elderly people in the country. The municipality of Pelotas is located in the southern region of Rio Grande do Sul, and has a population of 328,275 thousand inhabitants, with $15.3 \%$ in the age group of 60 years or more. Pelotas' rural area has a higher percentage of elderly people: of the 22,082 inhabitants, there are $15.8 \%$ of people aged above 60 years ${ }^{(2)}$.

The aging process may result in decline in physical and cognitive capacities, which can vary according to the life characteristics of each individual. The aging of society is an inevitable reality, a result of longer human longevity, to which dependence indexes are associated, due to worsening of previously acquired morbidity and greater vulnerability of the elderly ${ }^{(3)}$.

The elderly person in the rural context, in addition to the peculiarities of the aging process, shows a series of environmentrelated characteristics, such as the complexity of access to health services due to geographic and locomotion difficulties. Thus, health professionals/nurses who work in this area should develop skills directed to the needs of the elderly, considering the situations to which they are continually exposed. Professionals should use their skills in an expanded manner to fully assist the elderly, including cultural aspects in the care ${ }^{(4)}$.

This research seeks to deepen the study on the FS in the elderly in the rural population. Knowing the factors associated with FS in the elderly in this population is justified as necessary in order to plan activities according to the health conditions of these people. Systematic care for the frail elderly, as well as for those who are in the pre-frailty condition, aims to prevent the worsening and the evolution of preliminary stages of fragility to an advanced situation, seeking their autonomy, functionality and improved quality of life.

However, FS in the elderly is a dynamic process, in which evolution may change and even be prevented, if there is adequate diagnosis and care. Thus, it is necessary to plan health care aiming at prevention and rehabilitation activities to be applied individually, according to the need of each elderly person.

\section{OBJECTIVE}

Determine the prevalence and factors associated with FS in the elderly in residents from the rural community of Pelotas.

\section{METHOD}

\section{Ethical aspects}

This study complied with the terms of Resolution no. 466/2012(5), which deals with research involving human beings. The participants were informed of the research objectives and data confidentiality and, in agreeing freely to participate, signed the informed consent form. The project was approved by the Research Ethics Committee of the Federal University of Pelotas (UFPel) on May 19, 2014.

\section{Study design, location, and period}

This is a study with quantitative and analytical approach, crosssectional design, and was carried out between July and October 2014.

The target population consisted of 820 elderly individuals aged 60 years or older, registered in the Basic Health units (UBS) with Family Health Strategy (FHS), living in the rural area of the municipality of Pelotas (RS), Brazil.

The rural population is becoming composed of elderly people, and this process is intensified by the selective exodus of young people, a social phenomenon that characterizes the most recent period. Another factor to be considered is rural retirement, which increased the possibility of elderly people staying in this space ${ }^{(6)}$.

The municipality has 12 BHUs located in the rural area; of these, 10 have FHS, whose registered elderly participated in a draw to be part of the research. All the elderly from each record drawn were selected to participate in the research. The number of people selected in each BHU was proportional to the number of elderly people registered in the units.

\section{Sample, inclusion criteria, and exclusion criteria}

To calculate the sample of the main study, we used the following parameters and estimates: population size of 328,275 individuals in the municipality of Pelotas ${ }^{(1)}$, confidence level of $95 \%$, estimated prevalence of frailty in the elderly of $19.9 \%{ }^{(7)}$, and acceptable error of $3 \%$. With these parameters the initial calculation basis for the elderly was 680 plus $10 \%$ of losses and refusals and $10 \%$ to control confounding factors, totaling 823 elderly individuals. For this research, 834 elderly individuals were randomly selected, and 820 of these were interviewed.

The inclusion criteria were being aged 60 years or more, residing in the rural area of Pelotas - RS, and having been drawn by the researchers. We excluded individuals who were traveling, deprived of freedom by judicial decision, residing in long-stay institutions, or hospitalized during the data collection period in that locality.

\section{Study protocol}

Data was collected by volunteers, nursing students, and master's and doctoral students from the UFPel Graduate Nursing 
Program, previously trained. After the training, a pilot test was conducted with 10 elderly subjects from the rural area of Pelotas (one elderly subject for each collector) who were not part of the sample for data collection, in order to carry out the final analysis of the instrument and evaluate the performance of each interviewer. The elderly were selected by drawing the medical records of families registered in the FHS, and all the resident elderly people in the family records were listed to participate in the research. Then, the FHS health team assisted in locating the residence of the elderly people. All those drawn were informed about the study and, in accepting to participate, signed the free and informed consent form.

Chart 1 - Components of the self-reported assessment of frailty in the elderly, Pelotas, Rio Grande do Sul, Brazil, 2014

\begin{tabular}{|c|c|}
\hline $\begin{array}{l}\text { Self-reported } \\
\text { component of frailty }\end{array}$ & Questions and answers \\
\hline $\begin{array}{l}\text { Weight loss (scored } \\
\text { in this component } \\
\text { the elderly who } \\
\text { reported more than } \\
3 \mathrm{~kg})\end{array}$ & $\begin{array}{l}\text { In the last } 12 \text { months, have you lost weight } \\
\text { without following a diet? If so, how many kilos? } \\
\text { Between } 1 \mathrm{~kg} \text { and } 3 \mathrm{~kg} \\
\text { More than } 3 \mathrm{~kg} \\
\text { No }\end{array}$ \\
\hline Reduced strength & $\begin{array}{l}\text { In the last } 12 \text { months (last year), have you } \\
\text { been feeling weaker? Do you think your } \\
\text { strength has diminished? } \\
\text { Yes } \\
\text { No }\end{array}$ \\
\hline $\begin{array}{l}\text { Reduced walking } \\
\text { speed }\end{array}$ & $\begin{array}{l}\text { Do you think you walk slower nowadays } \\
\text { than you walked } 12 \text { months (one year) ago? } \\
\text { Yes } \\
\text { No }\end{array}$ \\
\hline Low physical activity & $\begin{array}{l}\text { Do you think you do less physical activity } \\
\text { than you did } 12 \text { months (one year) ago? } \\
\text { Yes } \\
\text { No }\end{array}$ \\
\hline \multirow[t]{2}{*}{$\begin{array}{l}\text { Reported fatigue } \\
\text { (scored in this } \\
\text { component the } \\
\text { elderly who reported } \\
\text { "sometimes" or } \\
\text { "most of the time" } \\
\text { in at least one of the } \\
\text { questions) }\end{array}$} & $\begin{array}{l}\text { How often, in the last week, have you felt } \\
\text { that you could not carry out your activities } \\
\text { (started something but could not finish it)? } \\
\text { Never or rarely (less than one day) } \\
\text { Few times (one to two days) } \\
\text { Sometimes (three to four days) } \\
\text { Most of the time }\end{array}$ \\
\hline & $\begin{array}{l}\text { How often, in the last week, did performing } \\
\text { your routine activities require a great effort } \\
\text { from you? } \\
\text { Never or rarely (less than one day) } \\
\text { Few times (one to two days) } \\
\text { Sometimes (three to four days) } \\
\text { Most of the time }\end{array}$ \\
\hline
\end{tabular}

Source: Nunes, Duarte, Santos and Lebrão(8).

The interviews occurred at the home of the elderly, with preservation of privacy and application of the structured and pre-coded questionnaire. The research instrument was answered by the elderly person or by the auxiliary or surrogate respondents, as proposed by Nunes, Duarte, Santos and Lebrão ${ }^{(8)}$.

For data collection, we used a standardized questionnaire that contained questions related to sociodemographic, clinical and lifestyle variables. We also applied the Mini Mental State Examination $(\mathrm{MMSE})^{(9)}$ for cognitive assessment and the Katz ${ }^{(10)}$ and Lawton ${ }^{(11)}$ questionnaires for functional capacity evaluation, and asked questions related to the occurrence of falls and to the criteria for evaluation of frailty ${ }^{(8)}$.

The theoretical framework consists of the independent variables associated with frailty: age $\geq 80$ years, female, black skin color, low income (up to 1 minimum wage, R\$ 724 in 2014), low educational level (up to 3 years of schooling), living alone, at least one hospitalization or institutionalization in the last year, at least one fall in the last year, morbidity (the elderly person has one or more pre-existing diseases), low weight (defined as body mass index $-\mathrm{BMI}=$ weight $(\mathrm{kg}) /$ height $(\mathrm{m})^{2}-$ below $22 \mathrm{~kg} / \mathrm{m}^{2}$ ), physical inactivity, poor or very poor self-perceived health, reduced functional capacity in the Katz scale ${ }^{(10)}$ - which evaluates the basic activities of daily living (the elderly were classified as "independent" when they reported need for help in zero activities, "mildly/moderately dependent" when they reported need for help in one to three activities, and "dependent" when they reported need for help in four to six activities) - and in the Lawton scale ${ }^{(11)}$ - which evaluates the instrumental activities of daily living (defined as partial dependence $=26-18$ points and dependence $\leq 18$ points) - , and cognitive deficit (Ministry of Health scores(9) for the MMSE, which considers as cognitive deficit for illiterate individuals the score below 19, as well as for individuals with one to three years of schooling the score below 23, from four to seven years of schooling the score below 24, and for those with longer schooling than seven years the score of 28).

As dependent variable, we defined frailty syndrome in the elderly checked by evaluating the self-reported components of frailty, as proposed by Nunes, Duarte, Santos and Lebrão ${ }^{(8)}$. As a criterion to classify the person as frail or non-frail (robust), we defined that zero component corresponds to non-frail, one to two components corresponds to pre-frail, and three or more components corresponds to frail ${ }^{(1,8)}$.

\section{Analysis of results and statistics}

Data were double-typed by independent typists in the software Epi Info 7.0 and then transferred to Stata 11.1 .

The analyses included the sample description in simple frequencies or mean and standard deviation, followed by bivariate analysis. All associations that resulted in $p$-value $\leq 0.20$ (indicator of indication of association) were taken to multivariate analysis to exclude confounding factors. Poisson regression was used with the robust variance method to adjust the data, thus enabling us to obtain the prevalence ratios and their corresponding $95 \%$ confidence intervals.

The adjusted analysis will take into account a hierarchical analysis model, in which there are four levels of determination. This model considers that the most distal levels influence the proximal ones, and these, in turn, affect the outcome of interest. 


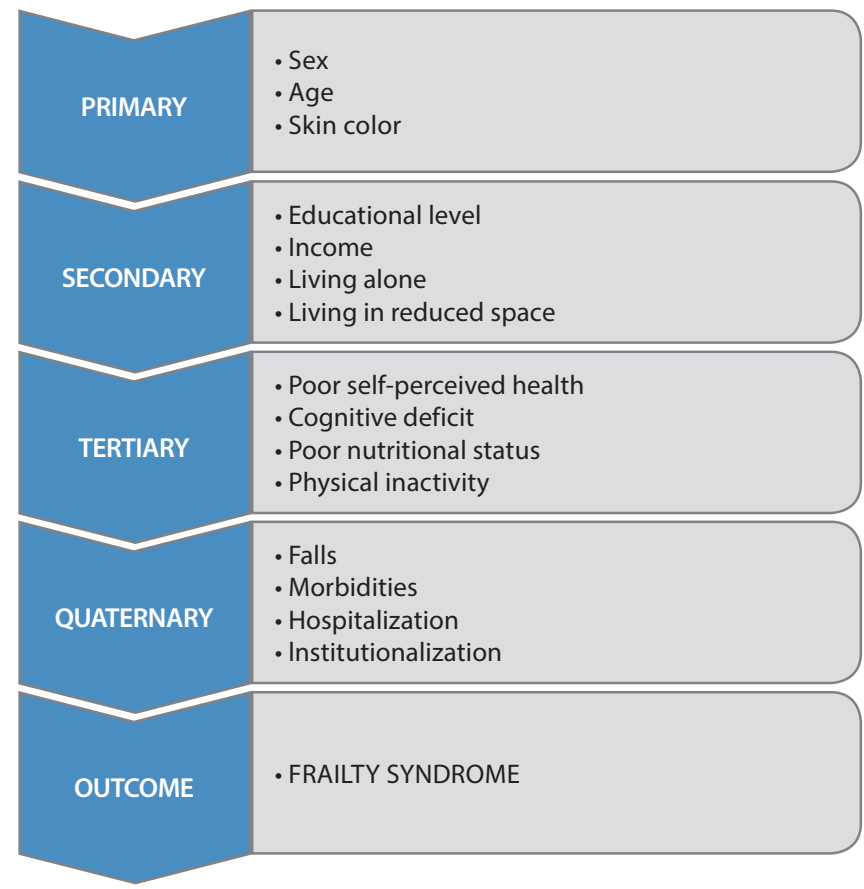

Figure 1 - Hierarchical model with the variables for data analysis, Pelotas, Rio Grande do Sul, Brazil, 2014

\section{RESULTS}

We randomly selected 834 elderly individuals to be part of this research. Of these, nine elderly individuals refused to participate after two invitations, and five elderly individuals were not found after five returns to their houses, resulting in a total of 820 respondents at the end of the study.

In the study, the age of the elderly ranged from 60 to 95 years, with the majority (54.9\%) aged between 60 and 69 years. Most were female $(58.99 \%)$, had white skin color (89.61\%), and lived with a partner (71.46\%). As for educational level, a large proportion of the elderly (40.85\%) had one to three years of schooling, $38.31 \%$ had four to seven years of schooling, $15.21 \%$ were illiterate, and $5.63 \%$ had eight years or more of schooling. As for cohabitation, $91.86 \%$ of these elderly people lived with other people - and concerning monthly income, most of them earned up to two minimum wages (79.77\%).

As for lifestyle and clinical variables, a large proportion of the elderly people showed overweight (42.69\%) and regular perception of health (44.67\%). Most of the elderly did physical activity $(67.41 \%)$, presented cognitive deficit (89.32\%), were independent for the basic activities of daily living (84.57\%), and were independent for instrumental activities of daily living (55.35\%). In the last 12 months $66.01 \%$ of them had falls, and $97.2 \%$ presented morbidities.

As for the frailty classification, $19.5 \%$ of the elderly were considered robust, $37.1 \%$ were pre-frail, and $43.4 \%$ were frail.

Table 1 showed significant association in raw analysis of FS in the elderly with variables of morbidity $(p=0.03)$, age of 80 years or more $(p=0.04)$, nutritional status $(p=0.005)$, falls $(p=0.001)$, hospitalization in the last year $(p=0.001)$, poor perception of health $(<p=0.001)$, cognitive deficit (MMSE; $<p=0.001)$, physical activity $(<p=0.001)$, and low educational level $(<\mathrm{p}=0.001)$. In addition, all variables with $p \leq 0.20$ (functional capacity, low income, and female sex) went to multivariate analysis, in order to obtain higher reliability in the results by excluding potential confounding factors.

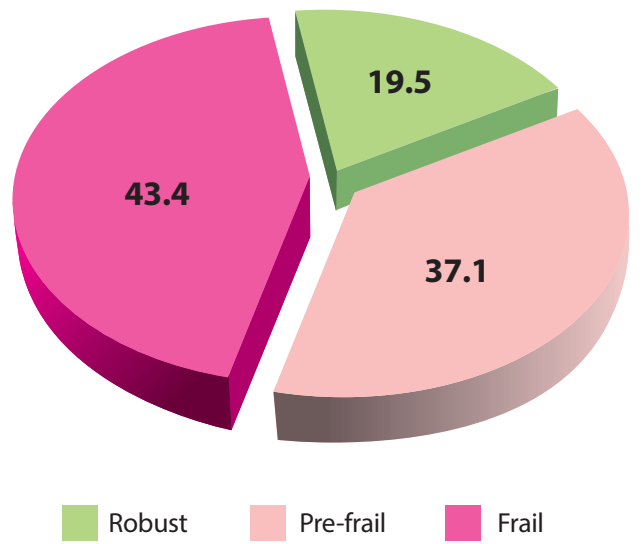

Figure 2 - Prevalence of self-reported frailty in the rural elderly, Pelotas, Rio Grande do Sul, Brazil, 2014 ( $N=820$ )

Table 1 - Vulnerability factors associated with frailty syndrome in the elderly from the rural area of Pelotas, Rio Grande do Sul, Brazil, 2014, bivariate analysis

\begin{tabular}{|c|c|c|c|}
\hline \multirow{2}{*}{ Variables } & \multicolumn{2}{|c|}{ Frailty } & \multirow{2}{*}{$p$ value } \\
\hline & No & Yes & \\
\hline Age $\geq 80$ years & & & 0.04 \\
\hline No & $398(85.75 \%)$ & $322(90.45 \%)$ & \\
\hline Yes & $66(14.25 \%)$ & 34 (9.55\%) & \\
\hline Skin color & & & 0.69 \\
\hline Not black & 453 (97.63\%) & 346 (97.19\%) & \\
\hline Black & $11(2.37 \%)$ & $10(2.81 \%)$ & \\
\hline Sex & & & 0.14 \\
\hline Male & $214(46.12 \%)$ & 146 (41.01\%) & \\
\hline Female & $250(53.88 \%)$ & 210 (58.99\%) & \\
\hline Living alone & & & 0.44 \\
\hline No & 419 (90.3\%) & 327 (91.85\%) & \\
\hline Yes & $45(9.7 \%)$ & $29(8.15 \%)$ & \\
\hline Living in reduced space & & & 0.63 \\
\hline No & 439 (94.61\%) & 334 (93.82\%) & \\
\hline Yes & $25(5.39 \%)$ & $22(6.18 \%)$ & \\
\hline Low income* & & & $0.16^{\# \#}$ \\
\hline No & $458(99.35 \%)$ & $348(98.31 \%)$ & \\
\hline Yes & $3(0.65 \%)$ & $6(1.69 \%)$ & \\
\hline Low educational level** & & & $<0.001$ \\
\hline No & $276(60.26 \%)$ & $156(43.94 \%)$ & \\
\hline Yes & $182(39.74 \%)$ & 199 (56.06\%) & \\
\hline Nutritional status *** & & & $0.005^{\# \#}$ \\
\hline Low weight & $8(1.79 \%)$ & 4 (1.15\%) & \\
\hline Eutrophy & 169 (37.72\%) & 93 (26.72\%) & \\
\hline Overweight & $176(39.28)$ & $152(43.68 \%)$ & \\
\hline Obesity & $95(21.21 \%)$ & $99(28.45 \%)$ & \\
\hline Physical activity**** & & & $<0.001$ \\
\hline No & $92(19.87 \%)$ & 115 (32.39\%) & \\
\hline Yes & $371(80.13 \%)$ & 240 (67.61\%) & \\
\hline Cognitive deficit & & & $<0.001$ \\
\hline No & $92(19.83 \%)$ & $38(10.67 \%)$ & \\
\hline Yes & 372 (80.17\%) & 318 (89.33\%) & \\
\hline
\end{tabular}


Table 1 (concluded)

\begin{tabular}{|c|c|c|c|}
\hline \multirow{2}{*}{ Variables } & \multicolumn{2}{|c|}{ Frailty } & \multirow{2}{*}{$p$ value } \\
\hline & No & Yes & \\
\hline Self-perceived health & & & $<0.001$ \\
\hline Very poor & $10(2.18 \%)$ & $40(11.27 \%)$ & \\
\hline Poor & $10(2.18 \%)$ & $32(9.01 \%)$ & \\
\hline Regular & $154(33.55 \%)$ & $158(44.51 \%)$ & \\
\hline Good & $232(50.54 \%)$ & 111 (31.27\%) & \\
\hline Very good & $53(11.55 \%)$ & $14(3.94 \%)$ & \\
\hline Institutionalization in the last year & & & $0.25^{\# \#}$ \\
\hline No & $464(100 \%)$ & 355 (99.72\%) & \\
\hline Yes & $0(0 \%)$ & $1(0.28 \%)$ & \\
\hline Hospitalization in the last year & & & $<0.001$ \\
\hline No & $419(90.3 \%)$ & 287 (80.62\%) & \\
\hline Yes & $45(9.7 \%)$ & $69(19.38 \%)$ & \\
\hline Functional capacity (Katz) & & & 0.11 \\
\hline Independent & $370(79.74 \%)$ & 301 (84.55\%) & \\
\hline Partially dependent & $82(17.67 \%)$ & $44(12.36 \%)$ & \\
\hline Totally dependent & $12(2.59 \%)$ & $11(3.09 \%)$ & \\
\hline Functional capacity (Lawton) & & & 0.07 \\
\hline Independent & $251(54.09 \%)$ & 197 (55.33\%) & \\
\hline Partially dependent & $170(36.64 \%)$ & $141(39.61 \%)$ & \\
\hline Totally dependent & $43(9.27 \%)$ & $18(5.06 \%)$ & \\
\hline Falls & & & 0.001 \\
\hline No & $356(76.72 \%)$ & 235 (66.01\%) & \\
\hline Yes & $108(23.28 \%)$ & $121(33.99 \%)$ & \\
\hline Morbidity & & & 0.03 \\
\hline No & $28(6.03 \%)$ & $10(2.81 \%)$ & \\
\hline Yes & $436(93.97 \%)$ & 346 (97.19\%) & \\
\hline
\end{tabular}

Note: ${ }^{*} N=815$ (five missing for the low income variable); ${ }^{*} N=813$ (seven missing for the low educational level variable); ${ }^{* *} N=796$ (24 missing for the nutritional status variable); ${ }^{* * * *} N$ $=218$ (two missing for the physical activity variable). \# Chi-square test. \#\# Fisher's exact test.

Table 2 shows the analysis adjusted hierarchically, by means of Poisson regression, with association between independent variables that obtained significance and frailty syndrome.

The factors consolidated as being associated with the condition of frailty were: low income, low educational level, nutritional status (obesity), physical inactivity, cognitive deficit, and poor self-perceived health, since there was significant association between these variables and frailty after multivariate analysis.

Table 2 - Risk factors for frailty syndrome in the elderly in the rural area of Pelotas, state of Rio Grande do Sul, Brazil, 2014, Poisson regression

\begin{tabular}{llcc}
\hline Variables & & $\begin{array}{c}\text { Adjusted prevalence } \\
\text { ratio (confidence } \\
\text { intervals of 95\%) }\end{array}$ & $\boldsymbol{p}$ value \\
\hline Age & 60-69 years & 1 & $=0.109$ \\
& 70-79 years & $0.76(0.57-1.01)$ & \\
& 80 years or more & $0.6(0.38-0.95)$ & \\
Sex $\quad$ Male & 1 & $=0.270$ \\
& Female & $1.13(0.96-1.32)$ & \\
Income & Up to two minimum wages & 1 & $<\mathbf{0 . 0 0 1}$ \\
& More than two minimum wages & $1.54(0.97-2.47)$ & \\
& & &
\end{tabular}

\begin{tabular}{|c|c|c|}
\hline Variables & $\begin{array}{l}\text { Adjusted prevalence } \\
\text { ratio (confidence } \\
\text { intervals of } 95 \% \text { ) }\end{array}$ & $p$ value \\
\hline Low educational level & & $<0.001$ \\
\hline No & 1 & \\
\hline Yes & $1.45(1.24-1.69)$ & \\
\hline Nutritional status & & $<0.001$ \\
\hline Eutrophy & 1 & \\
\hline Low weight & $0.91(0.27-3.1)$ & \\
\hline Overweight & $1.57(1.13-2.19)$ & \\
\hline Obesity & $1.89(1.3-2.77)$ & \\
\hline Physical activity & & $=0.003$ \\
\hline No & $1.93(1.41-2.66)$ & \\
\hline Yes & 1 & \\
\hline Cognitive deficit & & $<0.005$ \\
\hline No & 1 & \\
\hline Yes & $2.07(1.38-3.11)$ & \\
\hline Self-perceived health & & $<0.001$ \\
\hline Very poor/poor & $8.21(4.79-14.06)$ & \\
\hline Regular & $2.34(1.72-3.18)$ & \\
\hline Good/very good & 1.00 & \\
\hline Functional capacity (Katz) & & $=0.484$ \\
\hline Independent & 1 & \\
\hline Partially dependent & $0.66(0.44-1.08)$ & \\
\hline Totally dependent & $1.13(0.49-2.59)$ & \\
\hline Functional capacity (Lawton) & & $=0.353$ \\
\hline Independent & 1 & \\
\hline Partially dependent & $1.06(0.79-1.41)$ & \\
\hline Totally dependent & $0.53(0.3-1.12)$ & \\
\hline Falls in the last 12 months & & $=0.012$ \\
\hline No & 1 & \\
\hline Yes & $1.7(1.25-2.31)$ & \\
\hline Morbidity & & $=0.078$ \\
\hline No & 1 & \\
\hline Yes & $1.68(0.99-2.88)$ & \\
\hline
\end{tabular}

\section{DISCUSSION}

The prevalence of frailty found in this study was $43.41 \%$. In another study, conducted with 100 elderly participants from the geriatrics outpatient clinic of the São Lucas Hospital of the Pontifical Catholic University of Rio Grande do Sul (PUC-RS), located in Porto Alegre (RS), $31 \%$ of the elderly individuals were frail ${ }^{(12)}$. A study conducted with 139 elderly people registered in a Family Health Unit in southwestern Bahia shows that $16.9 \%$ are frail ${ }^{(13)}$. In a study on frailty in the elderly in Vietnam, which aimed to investigate the prevalence of frailty and its associated factors in elderly patients hospitalized in the National Geriatric Hospital in Hanoi, the prevalence of frail elderly individuals was $35.4 \%{ }^{(14)}$.

As for the variables that predispose to FS in the elderly, association with low income was observed, which is consistent with other studies conducted with elderly people in Brazil ${ }^{(15-16)}$. Having an unfavorable economic condition often leads the person to reside in a smaller household than advisable for good locomotion, with inadequate conditions to prevent accidents such as falls, even with possible hospitalizations and resulting functional incapacity and installation of FS in the elderly. According to the 
World Health Organization (WHO) ${ }^{(17)}$, the poor of all ages present a higher risk for diseases and disabilities, and the elderly are particularly vulnerable. Many of them, especially women, live alone or in rural areas with uncertain or insufficient income. These factors seriously affect their access to nutritious foods, adequate housing and health care, predisposing them to frailty syndrome.

Another factor that presents association with frailty is low educational level. In this study, the majority of the elderly had up to three years of schooling, and the mean level of education was 3.57 years studying. This finding is consistent with the study conducted with 257 home care clients aged 75 years or more who lived in three cities in Eastern and Central Finland; there was also association between low educational level and frailty ${ }^{(18)}$.

For ethnic-cultural contextualization, the elderly population researched was, mostly, of German origin and began their schooling in the 1950s. At that time, they had greater access to basic training due to the creation of community schools, which provided this education to the community, which justifies the reason why the elderly in the rural area of Pelotas were literate.

Another variable associated with FS in the elderly was obesity. Similar data were found in the study conducted with 1,457 elderly people in Portugal, which aimed to trace the frequency of frailty in a sample of Portuguese people aged 65 years or more and evaluate its associated factors, and obtained as a result that being obese increases the risk of frailty in the elderly ${ }^{(19)}$.

On this issue, the role of sarcopenic obesity can be suggested in the frailty process, which is characterized by excess fat coexisting with reduced lean mass, including muscles and bones. There is loss in quantity and quality of muscles, reducing the number and size of muscle fibers, mitochondrial function, and muscleprotein synthesis ${ }^{(20)}$.

Frailty was also associated with physical inactivity. In another study, conducted with 139 elderly people in the municipality of Jequié (BA), associations were also observed between frailty and lack of physical activity ${ }^{(13)}$. Reverse causality should be considered in cross-sectional studies, as this result may also mean that the elderly with FS may not perform physical activity. It promotes physical, functional, and mental aptitude, leading the elderly to a successful aging and with less predisposition to developing syndromes. In this context, in addition to tracing the elderly in the frailty process, health professionals/nurses need to encourage physical activity in adulthood and throughout the aging period.

Results from this research indicate that frailty was also associated with a subsequent decline in cognitive function. The association between the decline in cognitive function and frailty corroborates the findings of another study ${ }^{(21)}$. In it, the highest percentage of cognitive deficit was maintained in the elderly with more years of schooling, differently from the results found in a study that described a greater development of cognitive deficit occurring in the group of elderly people with no schooling ${ }^{(22)}$.

It is assumed, therefore, that the cutoff point for cognitive deficit is very rigid for the elderly with more than seven years of schooling, so this may legitimize the outcome of so many elderly people with cognitive deficit in this schooling range. In the rural context, the elderly always maintain the same work routine (regardless of Saturdays, Sundays and holidays); daylight guides activities. Thus, there may be a recollection bias in the MMSE questions referring to the day of the week, month, and/or time.
Moreover, the decline in cognitive functions associated with aging is related to external, behavioral, environmental, and social factors ${ }^{(3)}$. These factors, in all their totality, are responsible for the emergence of numerous pathological processes, contributing to increase incapacity in the elderly, which predisposes to frailty syndrome. Given the importance of cognitive decline for the frailty process, it is suggested a greater reflection on cognitive function as a potential criterion to be used to define frailty, which would better trace the vulnerability to the syndrome.

These findings denote the need to trace the elderly who are in the stage prior to frailty, thus increasing the possibilities of reducing risk factors for this condition. In addition, the health team/nurses must be prepared to perform preventive actions that reduce hospitalizations and, consequently, the progression of frailty.

With the aging process, all body systems may suffer losses, both in psychological and functional aspects. The lifestyle that people adopt in the course of their lives can intensify the aging process and lead to more severe declines, making them more vulnerable to the syndrome.

As for perception of health, researchers claim that unsatisfactory self-assessment of health status presented significant associations with the presence of diseases, which may justify its strong relation with the presence of frailty in the elderly. Elderly individuals with negative perception of health had more chances of developing FS, which is consistent with other studies ${ }^{(13-23)}$. With aging, the elderly show limitations and usually show dissatisfaction with their perception of health, which leads to a passive posture as to morbidities and loss of functional activities, accelerating their physical deterioration, increasing the likelihood of presenting frailty syndrome. Thus, frailtyfrom the perspective of a complex model - is associated with several components that interact dynamically and simultaneously constitute potential points of entry to or exit from the cycle of frailty ${ }^{(12)}$.

This result may be due to the elderly in the rural area doing activities that require greater effort, such as farming or raising cattle. Thus, they have better perception of the changes generated by aging, since they perceive routine activities being reduced, compared with previous years - a fact that can be easily perceived with the use of the self-reported instrument for frailty.

Given the need to modify adverse outcomes caused by the presence of frailty syndrome, some authors conclude that it is necessary to develop conducts aimed at prevention and health promotion for these elderly, since the frailty syndrome is complex and requires isolated actions to prevent, delay or hinder its progression in aging ${ }^{(24)}$.

Nurses should seek strategies that can promote the autonomy and independence of the elderly through the provision of individualized care, especially for those presenting with frailty or who are at risk of developing it ${ }^{(25)}$. Therefore, it is necessary that health professionals/nurses employ simple and validated assessment instruments, being able to know the associated factors and the components of frailty, in order to carry out an evaluation directed to these problems that affect the elderly.

It is perceived that the rural elderly with low educational level may be more likely to develop frailty syndrome due to the lower level of information. This may lead to a decrease in self-care and in continuous brain activity, which may result in a decline in cognitive functions. Accordingly, physical inactivity may lead to physical and mental inaptitude. 
The associations found may indicate the multifactorial nature of the FS in the elderly, which may lead to a natural outcome of the physiological aging process, as well as changes generated by social conditions, making them frail. However, health professionals/nurses should be prepared to plan the care provided to the elderly with FS in the immediate preventive and care aspects after the occurrence of the syndrome.

\section{Study limitations}

The research presents as a limitation a cross-sectional design that does not allow the establishment of a relation of cause and effect. However, the results of this research may contribute to deepen the knowledge on frailty syndrome among the rural elderly and contribute to the planning and implementation of care interventions and activities geared toward this condition, aiming to prevent, reverse, or hinder its progression.

\section{Contributions to the field of nursing, health or public policies}

The results of this research may lead health professionals to rethink the importance of frailty syndrome resulting from the aging process. Knowing the factors associated with frailty syndrome in the elderly becomes important, since it requires greater investment in the screening of frailty among elderly people and in the establishment of strategies for health promotion and prevention of their problems by health professionals. Nursing should be more knowledgeable about frailty syndrome in the elderly in order to prevent the occurrence of the problem and of the adverse and undesirable outcomes; this is a way of contributing to an active, healthy aging with more quality of life.

\section{CONCLUSION}

The following factors were consolidated as being associated with the condition of frailty: low income; low educational level; physical inactivity; obesity; cognitive deficit; and poor or very poor self-perceived health. The prevalence of frailty found in this study was $43.41 \%$.

Health care for the elderly, mainly due to the greater life expectancy and the various syndromes resulting from the aging process, requires greater investment in strategies for health promotion and disease prevention. In this context, we emphasize the importance of evaluating the elderly in the process of developing frailty, aiming at measures focusing on the factors that predispose to FS in the elderly.

\section{REFERENCES}

1. Fried LP, Tangem CM, Walston J, Newman AB, Hirsch C, Gottdiener J, et al. Frailty in older adults: evidence for a phenotype. J Gerontol A Biol Sci Med Sci [Internet]. 2001 [cited 2013 Apr 20];56(3):146-54. Available from: http://www.sld.cu/galerias/pdf/sitios/gericuba/fenotipo_frailty.pdf

2. Instituto Brasileiro de Geografia e Estatística - IBGE. Pelotas [Internet]. Brasília, DF; 2018 [cited 2019 May 8]. Available from: https://cidades. ibge.gov.br/brasil/rs/pelotas/panorama

3. Sequeira C. Cuidar de idosos com dependência física e mental. 2nd ed. Lisboa: Lidel; 2018.368p.

4. Ando NM, Targa LV, Almeida A, Silva DHS, Barros EF, Schwalm FD. Declaration of Brasília: "The concept of rural and the health care". Rev Bras Med Fam Comunidade [Internet]. 2011 [cited 2015 Jul 20];6(19):142-4. Available from: http://www.repositorio.ufop.br/ handle/123456789/3784

5. Conselho Nacional de Saúde (BR). Resolução n 466, de 12 de dezembro de 2012. Dispõe sobre as diretrizes e normas regulamentadoras de pesquisas envolvendo seres humanos. Diário Oficial da União [Internet]. 2013 June 13 [cited 2019 May 6];1:59. Available from: http://bvsms. saude.gov.br/bvs/saudelegis/cns/2013/res0466_12_12_2012.html

6. Rodrigues LR, Silva ATM, Dias FA, Ferreira PCS, Silva LMA, Viana DA, et al. Sociodemographic, economic and health profile of the rural elderly, according to depression indicators. Rev Eletrôn Enferm [Internet]. 2014 [cited 2013 Jun 8];16(2):278-85. Available from: https://www.fen.ufg. br/fen_revista/v16/n2/pdf/v16n2a02.pdf

7. Tribess S, Virtuoso Jr JS, Oliveira RJ. Physical activity as a predictor of absence of frailty in the elderly. Rev Assoc Med Bras [Internet]. 2012 [cited 2015 Jul 20];58(3):341-7. Available from: http://www.scielo.br/pdf/ramb/v58n3/en_v58n3a15.pdf

8. Nunes DP, Duarte YAO, Santos JLF, Lebrão ML. Screening for frailty in older adults using a self-reported instrument. Rev Saúde Pública [Internet]. 2015 [cited 2015 July 20];49:2. Available from: http://www.scielo.br/pdf/rsp/v49/pt_0034-8910-rsp-S0034-89102015049005516. pdfBrasil.

9. Ministério da Saúde (BR). Secretaria de Atenção à Saúde. Departamento de Atenção Básica. Envelhecimento e saúde da pessoa idosa. Brasília, DF; 2007.

10. Katz S, Akpom CA. A measure of primary sociobiological functions. Int J Health Serv [Internet]. 1976 [cited 2015 Apr 12];6(3):493-508. Available from: http://journals.sagepub.com/doi/pdf/10.2190/UURL-2RYU-WRYD-EY3K

11. Lawton MP, Brody EM. Assessment of older people: self maintaining and instrumental activities of daily living. Gerontologist [Internet]. 1969 [cited 2015 Apr 12];9(3):179-86. Available from: https://academic.oup.com/gerontologist/article-abstract/9/3_Part_1/179/552574?redirecte $\mathrm{dFrom}=$ fulltext

12. Vieira RA, Guerra RO, Giacomin KC, Vasconcelos KSS, Andrade ACS, Pereira LSM, et al. Prevalence of frailty and associated factors in community-dwelling elderly in Belo Horizonte, Minas Gerais State, Brazil: data from the FIBRA study. Cad Saúde Pública [Internet]. 2015 
[cited 2015 Jul 20];29(8):1631-43. Available from: http://www.scielo.br/pdf/csp/v29n8/v29n8a15.pdf

13. Santos PHS, Fernandes MH, Casotti CA, Coqueiro RS, Carneiro JAO. The profile of fragility and associated factors among the elderly registered in a Family Health Unit. Ciênc Saúde Coletiva [Internet]. 2015 [cited 2017 Mar 10];20(6):1917-24. Available from: http://www. scielosp.org/pdf/csc/v20n6/1413-8123-csc-20-06-1917.pdf

14. Vu HTT, Nguyen TX, Nguyen TN, Nguyen AT, Cumming R, Hilmer S, et al. Prevalence of frailty and its associated factors in older hospitalised patients in Vietnam. BMC Geriatric [Internet]. 2017 [cited 2018 Jun 21];17:216. Available from: https://www.ncbi.nlm.nih.gov/pmc/articles/ PMC5603186/

15. Fernandes $\mathrm{HCL}$, Gaspar JC, Yamashita CH, Amendola F, Alvarenga MRM, Oliveira MAC. Frailty assessment in the elderly assisted at a Family Heath Unit. Texto Contexto Enferm [Internet]. 2013 [cited 2017 Mar 10];22(2):423-31. Available from: http://www.scielo.br/pdf/tce/v22n2/ en_v22n2a19.pdf

16. Stort LB, Fabrício-Whebe SCC, Kusumota L, Partezani-Rodrigues R, Marques S. Frailty of elderly patients admitted to the medical clinic of an emergency unit at a general tertiary hospital. Texto Contexto Enferm [Internet]. 2013 [cited 2017 Mar 10];22(2):452-9. Available from: http:// dx.doi.org/10.1590/S0104-07072013000200022

17. World Health Organization-WHO. Active ageing: a policy framework. Brasília, DF: Organização Pan-Americana da Saúde; 2005.

18. Miettinen M, Tiihonen M, Hartikainen S, Nykänen I. Prevalence and risk factors of frailty among home care clientes. BMC Geriatr [Internet]. 2017 [cited 2018 Jun 21];17:266. Available from: https://www.ncbi.nlm.nih.gov/pmc/articles/PMC5693585/

19. Sousa-Santos AR, Afonso C, Moreira P, Padrão P, Santos A, Borges N, et al. Weakness: the most frequent criterion among pre-frail and frail older Portuguese. Arch Gerontol Geriatr [Internet]. 2018 [cited 2018 Jun 21];74:162-8. Available from: https://www.ncbi.nlm.nih.gov/ pubmed/29112877

20. Santos RR, Bicalho MAC, Mota P, Oliveira DR, Moraes EN. Obesity in the elderly. Rev Med Minas Gerais [Internet]. 2013 [cited 2017 Feb 4];23(1):64-73. Available from: http://rmmg.org/artigo/detalhes/12

21. Alencar MA, Dias JMD, Figueiredo LC, Dias RC. Frailty and cognitive impairment among community-dwelling elderly. Arq Neuropsiquiatr [Internet]. 2013 [cited 2016 Nov 10];71(6):362-7. Available from: http://www.scielo.br/pdf/anp/v71n6/0004-282Xanp-71-06-362.pdf

22. Faria CA, Lourenco RA, Ribeiro PCC, Lopes CS. Cognitive performance and frailty in older adults clients of a private health care plan. Rev Saúde Pública [Internet]. 2013 [cited 2016 Nov 10];47(5):1-8. Available from: http://www.scielo.br/pdf/rsp/v47n5/en_0034-8910rsp-47-05-0923.pdf

23. Pegorari MS, Tavares DMS. Factors associated with the frailty syndrome in elderly individuals living in the urban area. Rev Latino-Am Enferm [Internet]. 2014 [cited 2016 Nov 10];22(5):874-82. Available from: http://www.scielo.br/pdf/rlae/v22n5/0104-1169-rlae-22-05-00874.pdf

24. Lana LD, Schneide RH. The frailty syndrome in elderly: a narrative review. Rev Bras Geriatr Gerontol [Internet]. 2014 [cited 2016 Nov 10];17(3):670-80. Available from: http://www.scielo.br/pdf/rbgg/v17n3/1809-9823-rbgg-17-03-00673.pdf

25. Maciel GM, Santos RS, Santos TM, Menezes RMP, Vitor AF, Lira ALBC. Assessment of frailty in elderly people by nurse: integrative review. Rev Enferm Cent O Min [Internet]. 2016 [cited 2018 Apr 30];6(3):2430-8. Available from: http://www.seer.ufsj.edu.br/index.php/recom/article/ view/1010/1175 